\title{
Which adults in the Paris metropolitan area have never been tested for HIV? A 2010 multilevel, cross-sectional, population-based study
}

Véronique Massari ${ }^{1 *}$, Annabelle Lapostolle ${ }^{1}$, Marie-Catherine Grupposo ${ }^{1}$, Rosemary Dray-Spira ${ }^{1}$, Dominique Costagliola ${ }^{2}$ and Pierre Chauvin ${ }^{1}$

\begin{abstract}
Background: Despite the widespread offer of free HIV testing in France, the proportion of people who have never been tested remains high. The objective of this study was to identify, in men and women separately, the various factors independently associated with no lifetime HIV testing.

Methods: We used multilevel logistic regression models on data from the SIRS cohort, which included 3006 French-speaking adults as a representative sample of the adult population in the Paris metropolitan area in 2010. The lifetime absence of any HIV testing was studied in relation to individual demographic and socioeconomic factors, psychosocial characteristics, sexual biographies, HIV prevention behaviors, attitudes towards people living with HIV/AIDS (PLWHA), and certain neighborhood characteristics.

Results: In 2010, in the Paris area, men were less likely to have been tested for HIV at least once during their lifetime than women. In multivariate analysis, in both sexes, never having been tested was significantly associated with an age younger or older than the middle-age group (30-44 years), a low education level, a low self-perception of HIV risk, not knowing any PLWHA, a low lifetime number of couple relationships, and the absence of any history of STIs. In women, other associated factors were not having a child $<20$ years of age, not having additional health insurance, having had no or only one sexual partner in the previous 5 years, living in a cohabiting couple or having no relationship at the time of the survey, and a feeling of belonging to a community. Men with specific health insurance for low-income individuals were less likely to have never been tested, and those with a high stigma score towards PLWHA were more likely to be never-testers.

Our study also found neighborhood differences in the likelihood of men never having been tested, which was, at least partially, explained by the neighborhood proportion of immigrants. In contrast, in women, no contextual variable was significantly associated with never-testing for HIV after adjustment for individual characteristics.
\end{abstract}

Conclusions: Studies such as this one can help target people who have never been tested in the context of recommendations for universal HIV screening in primary care.

Keywords: HIV, Sexual behavior, Prevention, Gender, Multilevel, Cross-sectional studies, Social inequalities, Immigration status, Neighborhood

\footnotetext{
* Correspondence: veronique.massari@iplesp.upmc.fr

'Sorbonne Universités, UPMC Univ Paris 06, INSERM, Institut Pierre Louis Institute d'Epidémiologie et de Santé Publique (IPLESP UMRS 1136),

Department of Social Epidemiology, F-75012 Paris, France

Full list of author information is available at the end of the article
} 


\section{Background}

In high-income countries, publications on the barriers to and/or the facilitators of HIV testing remain scarce $[1,2]$, especially those focusing on the situation of their immigrant populations [3-7]. In France, because of the legal restrictions on collecting and processing data on ethnicity, religion and immigration status, there are few studies on the social and migrational determinants of HIV testing [8-10].

Despite universal access to HIV screening and treatment and one of the highest annual HIV testing rates in Europe (103 per 1,000 inhabitants) [11], the Paris region is characterized by a high proportion of HIV-positive tests (4.5 per 1,000 tests) and a large number of people who are unaware of their HIV infection (estimated at around 13,000 in a regional population of 11.9 million people) $[12,13]$. In this context, new screening strategies have been considered, which consist not only in promoting regular testing of high-risk individuals, but also in increasing the uptake of HIV screening by people who have never been tested. Indeed, in the past 5 years, the percentage of never-testers has decreased significantly but is still significant in this region. In 2010, a regional KABP survey found that $33.9 \%$ of men and $21.5 \%$ of women aged 18-54 years had never been tested during their lifetime (these proportions were $47.0 \%$ and $33.6 \%$ in 2004, respectively) [11]. The regional incidence of AIDS is estimated to be approximately 1,500 cases each year. In 2010, $60 \%$ of them were unaware of their HIV status at the time of diagnosis, and $40 \%$ had never been tested [14].

Our objectives were to collect certain socioeconomic status indicators, origin, sexual biographies, attitudes and behaviors regarding HIV testing and prevention, and neighborhood characteristics, in a representative sample of the adult, French-speaking population in the Paris metropolitan area and to determine those associated with no lifetime uptake of HIV testing.

\section{Methods}

The SIRS (a French acronym for health, inequalities and social ruptures) cohort is the first large, representative, population-based cohort created to study the social determinants of health and health-care utilization in the field of social epidemiology in France $[15,16]$. In 2005 , at inclusion, our study population was a multistage random sample of the adult French-speaking population living in the Paris metropolitan area (also called "Greater Paris", consisting of the City of Paris and its three adjacent départements, which constitute the core area of the entire Paris region, with 6.6 million inhabitants). The primary sampling units were census blocks including about 2000 inhabitants each. Fifty of them were randomly selected from the 2595 eligible census blocks according to their socioeconomic type. Subsequently, 60 households in each census block were chosen at random. Lastly, one adult in each household was randomly selected by the next-birthday method and interviewed at home.

In 2010, $47.2 \%$ of the 3006 participants included in 2005 were reinterviewed (2.6\% were deceased, $1.8 \%$ were too sick to answer our questions, $13.9 \%$ had moved out of the 50 surveyed IRISs, $2.7 \%$ were absent during the survey period, $18.4 \%$ declined to participate, and $13.4 \%$ were lost to follow-up). Their sex ratio and mean age were similar to those of the individuals who were not reinterviewed. The individuals lost to follow-up were younger and better off than the others, but neither their health status nor the socioeconomic type of their census block of residence was different. Those absent during the survey period had a lower socioeconomic status and were mostly immigrants. In each census block, the individuals who were not reinterviewed in 2010 were replaced by means of a random procedure similar to the one used in 2005, up to a final sample size of 60 adults interviewed per census block. The refusal rate among the newly contacted individuals was $29 \%$ (the same as in 2005).

In this paper, data collected in 2010 were examined cross-sectionally. The independent variables were selected from the SIRS dataset for the relevance of their association with HIV testing [17] or, more generally, with preventive health-care activities [18]. The analyses were limited to the 2621 subjects under 70 years of age to avoid a possible memory bias in the older individuals and to compare our data with those from other French studies.

\section{Ethics}

This cohort study had received legal authorization from two national authorities for non-biomedical research [19]: the Comité consultatif sur le traitement de l'information en matière de recherche dans le domaine de la santé (CCTIRS) (authorization number 904251) and the Commission nationale de l'informatique et des libertés (CNIL) (authorization number 05-1024). The participants provide their verbal informed consent. Written consent was not necessary because this survey did not fall into the category of biomedical research (as defined by French law) and did not collect any personal identification data.

\section{Measures}

\section{Outcome}

The outcome variable was no lifetime HIV testing.

\section{Demographics}

A first set of independent variables examined in this study consisted of demographics, which included age and 'immigration status'. The latter was defined and 
categorized on the basis of both the individual's and his/ her parents' nationality (at the time of the survey or of their death), distinguishing between French, born to two French parents; French, born to at least one foreign parent; and foreigners. Because HIV screening for all pregnant women had been widely offered since 1990 in France [20], having a child $<20$ years of age (or being pregnant at the time of the survey) was also considered.

\section{Socioeconomic status}

(SES)- Several characteristics related to the participants' SES were taken into account: education level (none or primary school, secondary school, and postsecondary), employment status (actively employed vs. all others, including unemployed, retired, student and inactive), occupational category (coded as never having worked, blue-collar, tradespeople/salespeople/shopkeepers and intermediate occupation, lower white-collar, and upper white-collar), and monthly income per consumption unit (CU), as calculated according to the OECD scale [21].

\section{Health care utilization status}

This dimension was explored by examining two variables: health insurance status and having or not having a regular general practitioner.

\section{HIV risk and stigma}

The participants' self-perception of HIV risk (ranked as low or high) and their knowing or not knowing people living with HIV/AIDS were taken into account. Five questions regarding attitudes towards PLWHA (namely, would accept to 1) work with them, 2) have a meal at their home, 3) go on vacation with them, 4) have protected sex with them, and 5) let them look after their children or grandchildren) were combined to calculate a stigma score, which ranged from 0 and 10 and increased with the level of negative attitude towards PLWHA. For each gender, this score was dichotomized into two categories $(\leq$ or $>2$, i.e., the mean score value for the entire population and also by gender).

\section{Sexual biographies, attitudes and behaviors}

The following variables were taken into account: selfreported sexual orientation (homosexual or bisexual, heterosexual, and not answered), the number of sexual partners of each sex, the number of sexual partnerships during the previous 5 years (one partnership, multiple partnerships or no partnerships), couple status at the time of the survey (no relationship, love affair, noncohabiting couple or cohabiting couple), and the lifetime number of couple relationships. The interviewees were also asked about their STI history (with a single question: "Have you ever had an STI?", with no further details).

\section{Social integration}

Certain characteristics pertaining to the participants' social ties and social support were taken into consideration as well: a feeling of being supported (or of not being supported) by friends, relatives or neighbors ("social support" in the rest of this paper), living (or not) living alone, a sense of belonging to a community, and their religious affiliation and practice, if any (but not their religion per se, as this would not have been very acceptable in France).

\section{Neighborhood characteristics}

At the neighborhood level, four socioeconomic characteristics of the census blocks of residence were considered. The mean monthly household income was calculated using the 2007 income tax database (provided by French tax authorities) and divided into quartiles. The proportions of immigrants, unemployed residents, and people with a low education level (no education or primary school) were available in the 2007 population census data provided by the French National Institute of Statistics and Economic Studies.

\section{Statistical analyses}

The differences in characteristics among the participants who reported having been tested at least once for HIV and those who had not were investigated using $X^{2}$ analysis or the Fisher exact test. Since sexual biographies, attitudes and behaviors vary according to gender [22, 23], all the analyses were stratified by sex. All of the univariate statistical analyses were weighted to take into account the sampling method and the poststratification adjustment for age and gender according to the 2007 general population census data [16]. A two-sided $p$-value $<0.05$ was considered statistically significant.

To build the final model for each sex, we used the following modeling strategy. First, a null model was computed to estimate the area-level variations without any covariables. Second, we considered three groups of independent variables (1. demographics and SES; 2 . the other individual variables, i.e., those concerning HIV risk and stigma toward PLWHA, sexual biographies, attitudes and behaviors, and social integration; and 3. the neighborhood variables) and performed a preselection of the independent variables associated with our outcome in each of these groups. To do this, all the variables associated with our dependant variable with a $p$-value $<0.20$ in univariate analysis (Table 1 ) were selected manually (using a backward-selection procedure based on the Hosmer \& Lemeshow approach [24] with a threshold $p<0.10)$ and checking for multicollinearity. Third, in Model 1, only the preselected demographic and socioeconomic variables were included and further selected using the same procedure but with a threshold $p<0.05$. Fourth, 
Table 1 Comparison of the characteristics of the HIV-tested and never-tested men $(n=1261)$ and women $(n=1360)$ in 2010

\begin{tabular}{|c|c|c|c|c|c|c|c|c|}
\hline & $\begin{array}{l}\text { Overall } \\
(n=2621)\end{array}$ & $\%$ & $\begin{array}{l}\text { Never-tested } \\
\text { men }(n=537)\end{array}$ & $\%$ & $\begin{array}{l}P \text {-value (tested } \\
\text { vs. never-tested) }\end{array}$ & $\begin{array}{l}\text { Never-tested } \\
\text { women }(n=451)\end{array}$ & $\%$ & $\begin{array}{l}P \text {-value (tested } \\
\text { vs. never-tested) }\end{array}$ \\
\hline \multicolumn{9}{|l|}{ Age } \\
\hline 18-29 years & 655 & 25.0 & $162 / 332$ & 48.7 & $<.0001$ & $133 / 323$ & 41.3 & $<.0001$ \\
\hline 30-44 years & 959 & 36.6 & $144 / 455$ & 31.6 & & $78 / 504$ & 15.5 & \\
\hline $45-59$ years & 700 & 26.7 & $143 / 332$ & 43.0 & & $140 / 367$ & 38.1 & \\
\hline 60-69 years & 308 & 11.7 & $89 / 142$ & 63.0 & & $99 / 166$ & 59.8 & \\
\hline \multicolumn{9}{|l|}{ Immigration status } \\
\hline French/French parents & 1688 & 64.4 & $329 / 832$ & 39.5 & .0031 & $257 / 856$ & 30.0 & .001 \\
\hline French/foreign parent (s) & 544 & 20.7 & $116 / 243$ & 48.0 & & $111 / 301$ & 36.7 & \\
\hline Foreigners & 389 & 14.8 & $92 / 187$ & 49.4 & & $83 / 203$ & 40.9 & \\
\hline \multicolumn{9}{|l|}{ Children and pregnancy } \\
\hline No child under 20 years of age & 1921 & 73.3 & $514 / 1201$ & 42.8 & .5360 & $333 / 720$ & 46.3 & $<.0001$ \\
\hline Child under 20 years of age ${ }^{a}$ & 701 & 26.7 & $23 / 60$ & 38.8 & & $118 / 640$ & 18.4 & \\
\hline \multicolumn{9}{|l|}{ Education level } \\
\hline None or primary school & 145 & 5.6 & $52 / 75$ & 68.8 & $<.0001$ & $50 / 70$ & 71.3 & $<.0001$ \\
\hline Secondary school & 941 & 35.9 & $234 / 468$ & 50.1 & & $173 / 473$ & 36.6 & \\
\hline Postsecondary & 1535 & 58.4 & $251 / 718$ & 35.0 & & $228 / 817$ & 27.9 & \\
\hline \multicolumn{9}{|l|}{ Employment status } \\
\hline Actively employed & 1940 & 74.0 & $386 / 1012$ & 38.1 & $<.0001$ & 233/928 & 25.1 & $<.0001$ \\
\hline All others & 682 & 26.0 & $151 / 249$ & 60.7 & & $218 / 432$ & 50.4 & \\
\hline \multicolumn{9}{|l|}{ Socio-occupational category } \\
\hline Never worked & 249 & 9.5 & $63 / 83$ & 76.4 & $<.0001$ & $91 / 166$ & 54.9 & $<.0001$ \\
\hline Blue collar & 190 & 7.2 & $88 / 162$ & 54.0 & & $13 / 27$ & 48.8 & \\
\hline Lower white-collar & 948 & 36.2 & $147 / 362$ & 40.7 & & $202 / 586$ & 34.5 & \\
\hline Tradespeople, salespeople & 479 & 18.1 & $93 / 238$ & 39.2 & & $74 / 237$ & 22.2 & \\
\hline Upper white-collar & 758 & 28.9 & $146 / 416$ & 35.1 & & $70 / 342$ & 20.5 & \\
\hline \multicolumn{9}{|l|}{ Monthly income (€/CU) } \\
\hline First quartile $(<1100)$ & 652 & 24.9 & $150 / 305$ & 49.2 & .0002 & $143 / 347$ & 41.4 & .0010 \\
\hline Second quartile (1100-1700) & 663 & 25.3 & $142 / 304$ & 46.8 & & $113 / 359$ & 31.5 & \\
\hline Third quartile (1701-2500) & 657 & 25.1 & $130 / 333$ & 39.0 & & $84 / 324$ & 27.3 & \\
\hline Fourth quartile ( $\geq 2501)$ & 649 & 24.8 & $115 / 319$ & 36.1 & & $106 / 330$ & 32.1 & \\
\hline Health insurance status & final & & & & & & & \\
\hline $\mathrm{HI}+$ additional insurance & 2104 & 80.4 & $416 / 976$ & 42.6 & 0.0380 & $345 / 1128$ & 30.6 & $<0.0001$ \\
\hline $\mathrm{HI}$ for the poor & 178 & 6.8 & $27 / 86$ & 31.4 & & $36 / 92$ & 39.1 & \\
\hline HI with no additional insurance & 335 & 12.8 & $94 / 198$ & 47.5 & & $66 / 137$ & 48.2 & \\
\hline \multicolumn{9}{|l|}{ Self-perception of HIV risk } \\
\hline High & 708 & 27.0 & $73 / 349$ & 20.9 & $<.0001$ & $49 / 359$ & 13.7 & $<.0001$ \\
\hline Low & 1913 & 73.0 & $465 / 912$ & 51.0 & & $402 / 1001$ & 40.1 & \\
\hline \multicolumn{9}{|l|}{ Knowing PLWHA } \\
\hline Yes & 1650 & 63.0 & $396 / 807$ & 49.1 & $<.0001$ & $341 / 844$ & 40.4 & $<.0001$ \\
\hline No & 971 & 37.0 & $141 / 455$ & 31.1 & & $110 / 516$ & 21.3 & \\
\hline \multicolumn{9}{|l|}{ Stigma towards PLWHA } \\
\hline Score $\leq 2$ & 1740 & 66.4 & $320 / 840$ & 38.1 & $<.0001$ & $267 / 900$ & 29.7 & .0002 \\
\hline
\end{tabular}


Table 1 Comparison of the characteristics of the HIV-tested and never-tested men $(n=1261)$ and women $(n=1360)$ in 2010 (Continued)

\begin{tabular}{|c|c|c|c|c|c|c|c|c|}
\hline Score $>2$ & 882 & 33.6 & $217 / 421$ & 51.6 & & $184 / 460$ & 39.9 & \\
\hline \multicolumn{9}{|l|}{ Self-reported sexual orientation } \\
\hline Heterosexual & 2515 & 95.9 & $522 / 1190$ & 43.9 & $<.0001$ & $435 / 1325$ & 32.9 & $<.0001$ \\
\hline Homo/bisexual & 75 & 2.9 & $6 / 58$ & 10.2 & & $1 / 16$ & 9.4 & \\
\hline Not answered & 31 & 1.2 & $10 / 13$ & 76.9 & & $14 / 19$ & 74.9 & \\
\hline \multicolumn{9}{|l|}{ Sexual partnerships during the previous 5 years } \\
\hline No partnerships & 243 & 9.3 & $43 / 84$ & 51.9 & $<.0001$ & $99 / 159$ & 61.9 & $<.0001$ \\
\hline One partnership & 1638 & 62.5 & $336 / 712$ & 47.2 & & $302 / 926$ & 32.6 & \\
\hline Multiple partnerships & 740 & 28.2 & $158 / 465$ & 33.9 & & $50 / 274$ & 18.1 & \\
\hline \multicolumn{9}{|l|}{ Couple status at the time of the survey } \\
\hline Not in a relationship & 569 & 21.7 & $143 / 279$ & 51.5 & $<.0001$ & $132 / 290$ & 45.7 & $<.0001$ \\
\hline Love affair & 335 & 12.8 & $50 / 157$ & 32.0 & & $59 / 178$ & 32.9 & \\
\hline Non-cohabiting couple & 156 & 5.9 & $21 / 82$ & 25.5 & & $15 / 73$ & 20.3 & \\
\hline Cohabiting couple & 1562 & 59.6 & $323 / 743$ & 43.4 & & $245 / 818$ & 29.9 & \\
\hline \multicolumn{9}{|l|}{ Lifetime number of couple relationships } \\
\hline None & 556 & 21.2 & $160 / 320$ & 50.0 & $<.0001$ & $116 / 237$ & 49.0 & $<.0001$ \\
\hline One & 1317 & 50.3 & $285 / 565$ & 50.5 & & $268 / 753$ & 35.6 & \\
\hline$\geq 2$ & 747 & 28.5 & $92 / 377$ & 24.5 & & $67 / 370$ & 18.0 & \\
\hline \multicolumn{9}{|l|}{ History of STI } \\
\hline No & 2260 & 86.2 & $513 / 1113$ & 46.1 & $<.0001$ & $409 / 1147$ & 35.7 & $<.0001$ \\
\hline Yes & 361 & 13.8 & $24 / 148$ & 16.4 & & $42 / 213$ & 19.5 & \\
\hline \multicolumn{9}{|l|}{ Feeling of being supported } \\
\hline Yes & 2597 & 99.1 & $533 / 1248$ & 42.7 & 0.561 & $443 / 1349$ & 32.8 & 0.0082 \\
\hline No & 24.5 & 0.9 & $5 / 14$ & 35.7 & & $8 / 11$ & 72.7 & \\
\hline \multicolumn{9}{|l|}{ Living alone } \\
\hline Yes & 414 & 15.8 & $75 / 223$ & 33.6 & 0.002 & $73 / 190$ & 38.4 & 0.1077 \\
\hline No & 2207 & 84.2 & $463 / 1038$ & 44.6 & & $378 / 1169$ & 32.3 & \\
\hline \multicolumn{9}{|l|}{ Sense of belonging to a community } \\
\hline No & 1806 & 68.9 & $347 / 872$ & 39.8 & .0024 & $273 / 934$ & 29.3 & $<.0001$ \\
\hline Yes & 815 & 31.1 & $191 / 390$ & 48.9 & & $177 / 426$ & 41.7 & \\
\hline \multicolumn{9}{|l|}{ Practice of a religion } \\
\hline Practices a religion regularly & 492 & 18.8 & $86 / 183$ & 47.1 & .1313 & $136 / 309$ & 44.0 & $<.0001$ \\
\hline Practices a religion but not on a regular basis & 483 & 18.4 & $85 / 199$ & 42.8 & & $97 / 284$ & 34.3 & \\
\hline Affiliation but does not practice & 699 & 26.7 & $154 / 353$ & 43.6 & & $101 / 346$ & 29.1 & \\
\hline No practicing or affiliation & 949 & 36.2 & $212 / 526$ & 40.4 & & $117 / 422$ & 27.8 & \\
\hline \multicolumn{9}{|l|}{ Neighborhood variables } \\
\hline \multicolumn{9}{|l|}{ Mean annual household income (€/CU) } \\
\hline First quartile $(<17,000)$ & 392 & 14.9 & 107/182 & 58.4 & $<.0001$ & $81 / 209$ & 38.8 & .0026 \\
\hline Second quartile $(17,000-21,999)$ & 673 & 25.7 & $146 / 330$ & 44.2 & & $133 / 343$ & 38.9 & \\
\hline Third quartile $(22,000-29,519)$ & 776 & 29.6 & $157 / 375$ & 41.8 & & $112 / 401$ & 28.0 & \\
\hline Fourth quartile $(\geq 29,520)$ & 780 & 29.8 & $128 / 373$ & 34.3 & & $124 / 406$ & 30.4 & \\
\hline \multicolumn{9}{|l|}{ Proportion of immigrants } \\
\hline First quartile & 791 & 30.2 & $155 / 378$ & 41.1 & .0001 & $113 / 413$ & 27.3 & .0011 \\
\hline
\end{tabular}


Table 1 Comparison of the characteristics of the HIV-tested and never-tested men $(n=1261)$ and women $(n=1360)$ in 2010 (Continued)

\begin{tabular}{|c|c|c|c|c|c|c|c|c|}
\hline Second quartile & 735 & 28.0 & $127 / 385$ & 33.1 & & $113 / 350$ & 32.3 & \\
\hline Third quartile & 585 & 22.3 & $111 / 257$ & 43.3 & & $124 / 327$ & 38.0 & \\
\hline Fourth quartile & 511 & 19.5 & $143 / 241$ & 59.4 & & $101 / 269$ & 37.4 & \\
\hline \multicolumn{9}{|c|}{ Proportion of unemployed persons } \\
\hline First quartile & 707 & 27.0 & $130 / 334$ & 39.0 & .0003 & $112 / 373$ & 29.9 & .0008 \\
\hline Second quartile & 835 & 31.9 & $156 / 399$ & 39.2 & & $134 / 436$ & 30.7 & \\
\hline Third quartile & 622 & 23.7 & $143 / 315$ & 45.5 & & $98 / 306$ & 32.0 & \\
\hline Fourth quartile & 457 & 17.4 & $107 / 213$ & 50.3 & & $107 / 244$ & 44.0 & \\
\hline \multicolumn{9}{|c|}{$\begin{array}{l}\text { Proportion of persons with a primary education } \\
\text { or less }\end{array}$} \\
\hline First quartile & 868 & 33.1 & $153 / 417$ & 36.7 & .0001 & $115 / 451$ & 25.4 & .0001 \\
\hline Second quartile & 831 & 31.7 & $162 / 406$ & 39.9 & & $141 / 425$ & 33.2 & \\
\hline Third quartile & 515 & 19.7 & $112 / 243$ & 46.3 & & $110 / 272$ & 40.3 & \\
\hline Fourth quartile & 406 & 15.5 & $110 / 195$ & 56.2 & & $85 / 211$ & 40.3 & \\
\hline
\end{tabular}

a including 42 pregnant women

in Model 2, the other individual variables previously preselected were added to Model 1 and backward-selected with a threshold $p<0.05$. Finally, all the contextual variables were added to Model 2 and selected in Model 3 in the same manner. Since no neighbourhood variable was found to be significantly associated in women, the final model was Model 2 (Table 3).

For each characteristic, the category with the lowest number of never-testers was used as the reference in the multivariate models. All the analyses used STATA software $\left(\right.$ STATA $^{\circ}$ v.12; STATA College Station, TX) with the xtmelogit procedure (specifying that collected data were clustered by census block). At each step, the level 2 variance was estimated to test for area-level variation, and the median odds ratio (MOR) was calculated. The MOR measures the median value of the adjusted OR between the most and least at-risk individual when comparing all pairs of neighborhoods [25].

\section{Results}

\section{Characteristics of the study population}

The sample consisted of 1261 men (48.1\%) and 1360 women $(51.9 \%)$. The participants' mean age $( \pm$ SD) at the time of the interview was $41.6( \pm 15.4)$ years for the men and $42.3( \pm 13.1)$ years for the women. With regard to SES (Table 1), 58.4 \% had a higher education level, $74.0 \%$ were actively employed, $21.7 \%$ were not in a couple relationship at the time of the survey, and $15.8 \%$ were living alone. A sense of belonging to a community was shared by $31.1 \%$ of the study population, and $37.2 \%$ practiced a religion.
In $2010,42.6 \%(n=537)$ of the men and $33.2 \%(n=$ $451)$ of the women reported that they had never been tested for HIV during their lifetime. The men were more likely to have never been tested for HIV than the women (42.6\% vs. $33.2 \%, p<0.001)$. Of the 1639 (62.0\%) participants tested at least once in their lifetime, $56.8 \%$ had been tested at least once at their request, $56.8 \%$ during a systematic or routine examination (including pregnancy, marriage, blood donations and preop exams), and $20 \%$ at their physician's request. Of the participants who had been tested, $39.7 \%$ had been so during the previous 24 months. The main reasons given for no testing were low risk perception (93\%), fear of HIV disease (3\%) and fear of HIV diagnosis disclosure (2\%).

The proportion of ever-testers varied greatly according to their neighborhood of residence, from $7.7 \%$ (95 \% CI: 0.0-19.6) to $85.7 \%$ (95 \% CI: 70.7-100.0) for the men, and from $19.3 \%$ (95\% CI: $2.3-36.3$ ) to $90.7 \%$ (95 \% CI: 80.1-100.0) for the women.

\section{Factors associated with no lifetime HIV testing in men}

In the men (Table 1), the factors associated with nevertesting for HIV in univariate analysis were a young ( $<29$ years) or an old age ( $>60$ years), being a foreigner or a French person born to at least one foreign parent, a lower education level, not being actively employed, being a blue-collar worker or never having worked, a lower income, having no additional health insurance, a low self-perception of HIV risk, not knowing any PLWHA, a high stigma score towards PLWHA, perceiving oneself as heterosexual or not answered, having had no or only one sexual partner during the previous 5 years, not 
being in a couple relationship or living in a couple relationship at the time of the survey, having had no or only one couple relationship in one's lifetime, not having a history of STIs, living alone, and the sense of belonging to a community. All the contextual variables tested were associated with the outcome. On the other hand, having a regular general practitioner, having social support and practicing a religion were not associated with no lifetime HIV testing in the men.

In multivariate multilevel analysis (Table 2), an arealevel effect was found in the null model (level 2 variance of 0.2898 [0.1087], $p=0.008$ ). Model 1 (with demographic and socioeconomic variables) showed that the factors associated with no lifetime HIV testing were all the age groups, except 30-44 years, a low or an intermediate education level, never having worked, and health insurance status (having health insurance specifically for lowincome individuals was associated with a lower likelihood of never having been tested than being insured through the usual system, with or without additional insurance). Introducing these characteristics reduced the level 2 variance by $14 \%$. In Model 2, the factors associated with our outcome included a low self-perception of HIV risk, a high stigma score towards PLWHA, not knowing any PLWHA, having had no or only one lifetime couple relationship, and not having a history of STIs. Introducing these characteristics led to a $53 \%$ reduction in the initial level 2 variance. When further introducing neighborhood characteristics, only the proportion of immigrants in the neighborhood of residence was significant. In Model 3, the area-level variance $(0.0978$ [0.0803]) was no more significantly different from zero when both the individual and area-level variables were taken into account, and the MOR gradually decreased from 1.67 in the empty model to 1.35 in the full model.

\section{Factors associated with no lifetime HIV testing in women}

In the women (Table 1), the factors positively associated with never-testing for HIV in univariate analysis were a younger ( $<29$ years) or an older age ( $>60$ years), being a foreigner or a French person born to at least one foreign parent, not having a child $<20$ years of age, a low education level, not being actively employed, being a blue-collar worker or never having worked, a lower income, not having additional health insurance or having insurance for low-income individuals, a low self-perception of HIV risk, not knowing any PLWHA, a high stigma score towards PLWHA, being self-reported as heterosexual or not answered, having had no or only one sexual partner during the previous 5 years, not being in a couple relationship at the time of the survey, never having been in a couple relationship, not having a history of STIs, weak social support, a sense of belonging to a community, and practicing a religion on a regular basis. On the other hand, neither having a regular practitioner nor living alone was associated with never having been tested for HIV. All the contextual variables were significantly associated with the outcome.

In multivariate multilevel analysis (Table 3), an arealevel effect was found in the null model (area-level variance of 0.1864 [0.0698], $p=0.008$ ). The following characteristics were selected in Model 1: the age groups other than 30-44 years, being a foreigner, not having a child $<20$ years of age, a low or intermediate education level, not being actively employed, never having worked or being in an intermediate socio-occupational category, and not having additional health insurance. Introducing these characteristics reduced the level 2 variance by $38 \%$, and the area-level variance $(0.1179$ [0.0637]) was no more significantly different from zero. In Model 2, the attitudes and behavioral factors associated with never having been tested for HIV included a low self-perception of HIV risk, not knowing any PLWHA, a high stigma score towards PLWHA, having had no or only one sexual partner during the previous 5 years, not being in a couple relationship or being in a cohabiting couple relationship at the time of the survey, never having been in a couple relationship, not having a history of STIs, and a sense of belonging to a community. In the full model, the only neighborhood variable selected in the absence of any individual covariables (the neighborhood proportion of inhabitants with a low education level) was not significantly associated with the outcome. Overall, the successive adjustments had smaller impacts on level 2 variance and MOR in the woman than in the men.

\section{Discussion}

In addition to the socioeconomic factors usually observed to be associated with prevention attitudes and practices, we found that the absence of any lifetime HIV testing was associated with a low risk perception, health insurance status, not knowing any PLWHA, a high stigma score towards PLWHA, a low lifetime number of couple relationships, the absence of any history of STIs and, for men only, the neighborhood proportion of immigrants.

Our sample was limited to the Paris metropolitan area, which limits its external validity, particularly in nonurban contexts. However, since this region bears the largest part of the HIV burden in mainland France, our conclusions could be useful in helping manage the epidemic [26]. Unfortunately, because of the sampling design, we were unable to reach the most vulnerable populations, such as homeless people (among whom immigrants are overrepresented) [27]. Also, we interviewed only French-speaking individuals, thereby excluding still more foreigners but non-French-speaking individuals accounted for $5 \%$ of the initial sample. If they had been included in the SIRS 
Table 2 Factors associated with never-testing for HIV among men $(n=1261)$ as determined by multilevel multivariate logistic regression

\begin{tabular}{|c|c|c|c|c|}
\hline & & $\begin{array}{l}\text { Model } 1 \\
\text { aOR [95 \% Cl] }\end{array}$ & $\begin{array}{l}\text { Model } 2 \\
\text { aOR }[95 \% \mathrm{Cl}]\end{array}$ & $\begin{array}{l}\text { Model } 3 \\
\text { aOR }[95 \% \mathrm{Cl}]\end{array}$ \\
\hline \multicolumn{5}{|c|}{ Individual variables } \\
\hline \multirow[t]{4}{*}{ Age } & 18-29 years & $2.07[1.32-3.24]$ & $1.88[1.11-3.24]$ & $1.86[1.08-3.18]$ \\
\hline & $30-44$ years & Ref. & Ref. & Ref. \\
\hline & $45-59$ years & $1.38[0.97-1.96]$ & $1.76[1.20-2.58]$ & $1.77[1.21-2.59]$ \\
\hline & $60-69$ years & $2.89[1.88-4.42]$ & $3.16[1.98-5.04]$ & $3.23[2.02-5.14]$ \\
\hline \multicolumn{5}{|l|}{ Education level } \\
\hline & None or primary school & $3.29[1.83-5.94]$ & $2.82[1.49-5.33]$ & $2.51[1.32-4.78]$ \\
\hline & Secondary school & $1.77[1.24-2.51]$ & $1.72[1.18-2.52]$ & $1.63[1.11-2.39]$ \\
\hline & Postsecondary & Ref. & Ref. & Ref. \\
\hline \multicolumn{5}{|c|}{ Socio-occupational category } \\
\hline & Never worked & 3. $33[1.42-7.76]$ & 3.62 [1.44-9.09] & $3.34[1.34-8.33]$ \\
\hline & Blue collar & $1.24[0.73-2.09]$ & $1.06[0.60-1.89]$ & $0.99[0.56-1.77]$ \\
\hline & Lower white-collar & $0.81[0.52-1.24]$ & $0.74[0.46-1.18]$ & $069[0.43-1.10]$ \\
\hline & Tradespeople, etc. & $0.91[0.59-1.40]$ & $0.95[0.60-1.52]$ & $0.90[0.56-1.44]$ \\
\hline & Upper white-collar & Ref. & Ref. & Ref. \\
\hline \multicolumn{5}{|c|}{ Health insurance status } \\
\hline & $\mathrm{HI}+$ additional insurance & $2.30[1.29-4.09]$ & $2.23[1.19-4.18]$ & $2.34[1.24-4.39]$ \\
\hline & HI for the poor & Ref. & Ref. & Ref. \\
\hline & HI with no additional insurance & $2.43[1.28-4.63]$ & $2.43[1.21-4.87]$ & $2.46[1.22-4.94]$ \\
\hline \multicolumn{5}{|c|}{ Self-perception of HIV risk } \\
\hline & High & & Ref. & Ref. \\
\hline & Low & & $3.41[2.29-5.08]$ & $3.33[2.24-4.96]$ \\
\hline \multicolumn{5}{|l|}{ Knowing PLWHA } \\
\hline & Yes & & ref & ref \\
\hline & No & & $1.54[1.09-2.18]$ & $1.57[1.12-2.22]$ \\
\hline \multicolumn{5}{|c|}{ Stigma towards PLWHA } \\
\hline & Score $\leq 2$ & & Ref. & Ref. \\
\hline & Score $>2$ & & $1.70[1.23-2.34]$ & $1.67[1.21-2.30]$ \\
\hline \multicolumn{5}{|c|}{ Lifetime number of couple relationships } \\
\hline & None & & $2.96[1.75-5.00]$ & $2.97[1.75-5.01]$ \\
\hline & One & & $2.19[1.53-3.14]$ & $2.16[1.51-3.10]$ \\
\hline & $\geq 2$ & & Ref. & Ref. \\
\hline \multicolumn{5}{|l|}{ History of STI } \\
\hline & Yes & & Ref. & Ref. \\
\hline & No & & $2.88[1.64-5.07]$ & $2.89[1.65-5.06]$ \\
\hline \multicolumn{5}{|c|}{ Neighborhood variables } \\
\hline \multicolumn{5}{|c|}{ Proportion of immigrants } \\
\hline & First quartile & & & $1.04[0.64-1.70]$ \\
\hline & Second quartile & & & ref \\
\hline & Third quartile & & & $1.12[0.68-1.85]$ \\
\hline & Fourth quartile & & & $1.98[1.18-3.33]$ \\
\hline Level 2 variance & & $0.2495(0.1064)$ & $0.1545(0.0942)$ & $0.0978(0.0803)$ \\
\hline
\end{tabular}


Table 2 Factors associated with never-testing for HIV among men $(n=1261)$ as determined by multilevel multivariate logistic regression (Continued)

\begin{tabular}{llll}
\hline$p$-value & 0.019 & 0.101 & 0.223 \\
MOR & 1.61 & 1.45 & 1.35 \\
\hline
\end{tabular}

Empty model: level 2 variance $=0.2898(0.1087) ; p=0.008 ; \mathrm{MOR}=1.67$

cohort, the difference between French persons and foreigners may have been accentuated by the inclusion of more individuals not reached by prevention messages.

The participants were interviewed retrospectively about any previous HIV testing. The last test had been performed on average about 5 years before the survey date. Thus, there was a possible recall bias concerning the circumstances of the last test. In addition, some respondents may have confused certain routine laboratory tests with the HIV screening test, which would have led to an overestimation of HIV testing, especially among recent immigrants and less educated and/or less health-literate individuals.

Many studies on the utilization of health-care services have shown that people with a low SES are less likely to avail themselves of preventive care, even in countries where national health services and/or universal health insurance should preclude any financial obstacles to such care [28]. For instance, we reported similar socioeconomic gradients in women's cancer screening in the same survey population $[29,30]$.

Taking into account certain indicators of sexual behaviors and attitudes toward PLWHA enabled us to explore the contribution of these factors to some but not all of the observed socioeconomic and demographic differences. In particular, due to a lack of statistical power, we were unable to find a significant association with (self-reported) sexual orientation, since the number of participants who indicated that they were bi- or homosexual was too small in both genders (58 men and 16 women). Moreover, these numbers were probably underestimated, particularly in certain immigrant populations where sexuality and especially homosexuality are still taboo and/or punished by law in their country of origin [31].

The fact that younger people of both sexes were less likely to have been tested for HIV is particularly worrisome. Of course, HIV prevalence in young heterosexual people remains low, with the result that they are not the most at risk for HIV exposure (until now). However, a recent KABP study in the French capital region found that people in this age group had a poorer knowledge and a weaker perception of HIV risk compared not only to the other age groups in 2010, but also to the same age group interviewed previously, between 1992 and 2004 [26]. Indeed, in our study, $70.5 \%$ of the men and $34.2 \%$ of the women in this age group reported that they had had more than one sexual partner during the previous 5 years (compared to $24.9 \%$ and $14.5 \%$, respectively, of the rest of the population), while in a regional KABP study, only $39 \%$ of the men and $27 \%$ of the women in this age group indicated that they had used a condom at last intercourse (compared to $45 \%$ and $36 \%$ in 2004, respectively) [26]. We also observed, in a previous analysis, that of the 655 HIV-negative individuals aged 18 to 29 years who had answered the question about their intention regarding protection in 2010, 376 (57.4 \%) reported that they consistently used condoms to protect themselves from HIV (men more often than women: $71.0 \%$ vs. $43.3 \%$, respectively, $p<0.001$ ) [32].

We also observed that older age was independently associated with never-testing for HIV in both genders. The recent ANRS-Vespa2 study found that older people were also at higher risk for late presentation of HIV in all the subpopulations that were specifically examined, e.g., heterosexual male and female immigrants born in sub-Saharan Africa or North Africa and North Africans who practice a religion. Moreover, MSM over 50 who did not define themselves as gay were at higher risk for late HIV diagnosis [33]. Such a lower level of HIV testing in older individuals could certainly have major consequences on the epidemiology of HIV infection.

In a previous analysis of the same cohort in 2005 (with far fewer individual characteristics obtained by interview and analyzed), we found that gender, socioeconomic status, immigration status and neighborhood of residence were barriers to HIV testing in the adult population in the Paris metropolitan area [17]. We also found that measures aimed at increasing HIV testing in sub-Saharan immigrants may have been effective, given that people from sub-Saharan Africa were more likely to have been tested in their lifetime $(78.5 \%)$ than those of French $(56.2 \%)$ or Maghreb $(39.7 \%)$ origin $(p<0.0001)$ [34]. In 2010, we found that women with a sense of belonging to a community and, to a lesser extent, foreign women were less likely to have been HIV-tested than other women. Actually, these two characteristics are obviously correlated, given that a sense of belonging to a community is shared by $49 \%$ of foreign women and $45 \%$ of French women born to at least one foreign parent (compared to $22 \%$ of French women born to French parents, $p<0.0001)$. In men, these figures were, respectively, $49 \%, 45 \%$ and $22 \%$ $(p<0.0001)$. 
Table 3 Factors associated with never-testing for HIV among women $(n=1360)$ as determined by multilevel multivariate logistic regression

\begin{tabular}{|c|c|c|c|}
\hline & & $\begin{array}{l}\text { Model } 1 \\
\text { aOR [95 \% Cl] }\end{array}$ & $\begin{array}{l}\text { Model } 2 \\
\text { aOR [95 \% Cl] }\end{array}$ \\
\hline \multicolumn{4}{|l|}{ Individual variables } \\
\hline \multirow[t]{4}{*}{ Age } & $18-29$ years & $1.70[1.12-2.56]$ & $1.66[1.04-2.66]$ \\
\hline & $30-44$ years & Ref. & Ref. \\
\hline & $45-59$ years & 2.15 [1.54-2.99] & $2.18[1.50-3.17]$ \\
\hline & $60-69$ years & $2.55[1.60-4.05]$ & $2.69[1.57-4.62]$ \\
\hline \multicolumn{4}{|l|}{ Immigration status } \\
\hline & French/French parents & Ref. & Ref. \\
\hline & French/foreign parent (s) & $1.25[0.91-1.73]$ & $1.07[0.75-1.55]$ \\
\hline & Foreigner & $1.55[1.06-2.27]$ & $1.37[0.89-2.10]$ \\
\hline \multicolumn{4}{|l|}{ Child under 20 years of age } \\
\hline & Yes & Ref. & Ref. \\
\hline & No & $2.94[2.17-3.99]$ & $3.49[2.41-5.07]$ \\
\hline \multicolumn{4}{|l|}{ Education level } \\
\hline & None or primary school & 3.04 [1.77-5.23] & $2.61[1.45-4.71]$ \\
\hline & Secondary school & $1.57[1.15-2.12]$ & $1.52[1.08-2.13]$ \\
\hline & Post-secondary & Ref. & Ref. \\
\hline \multicolumn{4}{|l|}{ Employment status } \\
\hline & Actively employed & Ref. & Ref. \\
\hline & All others & $1.54[1.12-2.12]$ & $1.11[0.78-158]$ \\
\hline \multicolumn{4}{|l|}{ Socio-occupational category } \\
\hline & Never worked & 2.39 [1.39-4.10] & $1.81[0.99-3.27]$ \\
\hline & Blue collar & 1.28 [0.59-2.80] & $1.02[0.44-2.36]$ \\
\hline & Lower white-collar & $1.30[0.88-1.91]$ & $1.12[0.74-1.72]$ \\
\hline & Tradespeople, etc. & $1.71[1.15-2.54]$ & $1.82[1.18-2.80]$ \\
\hline & Upper white-collar & Ref. & Ref. \\
\hline \multicolumn{4}{|l|}{ Health insurance status } \\
\hline \multirow[t]{2}{*}{$\mathrm{HI}+$ additional insurance } & Ref. & Ref. & \\
\hline & $\mathrm{HI}$ for the poor & $0.95[0.58-1.54]$ & $1.29[0.75-2.22]$ \\
\hline HI with no additional insurance & $1.72[1.15-2.57]$ & $2.09[1.32-3.32]$ & \\
\hline \multicolumn{4}{|l|}{ Self-perception of HIV risk } \\
\hline & High & & Ref. \\
\hline & Low & & $5.04[3.43-7.41]$ \\
\hline \multicolumn{4}{|l|}{ Knowing PLWHA } \\
\hline & Yes & & Ref. \\
\hline & No & & $2.01[1.49-2.71]$ \\
\hline \multicolumn{4}{|c|}{ Sexual partnerships during previous 5 years } \\
\hline & No partnerships & & $2.15[1.26-3.67]$ \\
\hline & One partnership & & $1.73[1.12-2.68]$ \\
\hline & Multiple partnerships & & Ref. \\
\hline \multicolumn{4}{|c|}{ Couple status at the time of the survey } \\
\hline & No relationship & & $2.35[1.15-4.78]$ \\
\hline & Love affair & & $2.03[0.97-4.27]$ \\
\hline
\end{tabular}


Table 3 Factors associated with never-testing for HIV among women $(n=1360)$ as determined by multilevel multivariate logistic regression (Continued)

$\begin{array}{lc}\text { Non-cohabiting couple } & \text { Ref. } \\ \text { Cohabiting couple } & 3.25 \text { [1.57-6.72] }\end{array}$

Lifetime number of couple relationships

$\begin{array}{ll}\text { None } & 2.63[1.55-4.46] \\ \text { One } & 1.39[0.99-1.93] \\ \geq 2 & \text { Ref. }\end{array}$

History of STI

No

Yes

Sense of belonging to a community

\begin{tabular}{llcc} 
& Yes & & 1.33 [0.99-1.79] \\
Ref. & $0.1655(0.0804)$ \\
Level 2 variance & No & $0.1179(0.0637)$ & 0.039 \\
P-value & & 0.064 & 1.47 \\
MOR & & 1.39 & 1.47 \\
\hline
\end{tabular}

$1.62[1.05-2.50]$ Ref.

Empty model: level 2 variance $=0.1864(0.0698) ; p=0.008 ; \mathrm{MOR}=1.51$

In our study, we found that individuals with a low lifetime number of couple relationships were less likely to have been tested. Another French study among latetested HIV-positive individuals found that both male and female heterosexuals in a steady relationship and with children felt that they were less at risk for HIV infection and that this put them at greater risk for never having been tested in the absence of symptoms [35]. Generally speaking, since they are not priority targets for testing promotion, individuals at low risk for HIV infection are at high risk for not being tested for HIV and for late diagnosis [36]. In our study, a low self-perceived risk for HIV infection was associated with no HIV testing in both sexes. Some studies have reported similar observations in immigrants in Portugal [6] and Spain [7], and in pregnant women in other European countries [2, 37, 38]. Deblonde et al., in a systematic review in Europe, found that the main barrier to HIV testing are a low risk perception, fear of HIV disease and of HIV diagnosis disclosure, and lack of access to health services. In our study. the two responses (fear of disease and fear of disclosure) were given, respectively, by only $3 \%$ and $2 \%$ of the never-testers. A minor gradient was observed for fear of disclosure according to immigration status in both sexes (respectively, $0 \%, 0.5 \%$ and $8.4 \%$ in the women and $1 \%, 1.8 \%$ and $2.7 \%$ in the men).

The men with a high stigma score towards PLWHA and those who did not know any PLWHA among family, friends or coworkers were more likely to be nevertesters. As suggested by Burkholder et al. [39], since they do not empathize or identify with PLWHA, people who stigmatize them cannot perceive themselves as possibly being concerned by this matter or at risk for HIV infection. In other words, people with stigmatizing attitudes may perceive a greater distance between themselves and those with the disease [31]. Stigma serves to emphasize and enhance the differences between the stigmatizers and those being stigmatized [40].

The association observed between no HIV testing and no history of STIs could be due to the fact that French health authorities recommend proposing an HIV test whenever an STI is suspected [41]. Practically, this recommendation seems to be followed by some health professionals but not a majority of them. Indeed, in a French study in newly diagnosed HIV-infected people carried out in 2010, only half of the individuals with STIs during the 3 years prior to HIV diagnosis had actually received an HIV testing proposal from a health-care provider [42].

Lastly, our study found a contextual effect on no lifetime HIV testing in men. Indeed, the decrease in the level 2 variance and its $p$-values showed that introducing the proportion of immigrants living in the neighborhood of residence explained part of the observed differences between neighborhoods. In contrast, in women, the significant differences in the observed crude prevalence rates of HIV testing between neighborhoods were mainly explained by a composition effect (i.e., by individual characteristics).

The men living in neighborhoods with a high proportion of immigrants (more than $28 \%$ ) were two times less likely to have been HIV-tested those living in neighborhoods with a proportion of immigrants between 17 and $23 \%$. This could be explained by a number of norms 
shared by immigrant men in these neighborhoods, such as the fear of stigmatization or discrimination related to being tested for HIV (regardless of the result). Indeed, we observed that foreigners and French persons born to at least one foreign parent were more likely to have a positive stigma score than French persons born to French parents $(61.0 \%, 48.2 \%$ and $34.3 \%$, respectively, in men, $p<0.0001 ; 60.2 \%, 48.4 \%$ and $31.3 \%$, respectively, in women, $p<0.0001)$. Similarly, foreigners and French persons born to at least one foreign parent were less likely to report that they knew a PLWHA than French persons born to French parents, (19.2\%, $28.8 \%$ and $39.0 \%$, respectively, in men, $p<0.0001 ; 28.7 \%$, $27.6 \%$ and $42.2 \%$, respectively, in women, $p<0.0001$ ). Lastly, not knowing any PLWHA was significantly associated with a positive stigma score: $47.6 \%$ of the men who did not know any PLWHA had a positive stigma score versus $28.1 \%$ of those who did $(p<0.001)$. In the women, these figures were, respectively, $47.9 \%$ and $23.6 \%(p<0.001)$.

No lifetime HIV testing could also be a consequence of differentiated practices by health professionals according to their patients' social or demographic characteristics. For instance, in 2003, a French study found that the factors associated with the lack of proposing HIV/AIDS and hepatitis $\mathrm{B}$ and $\mathrm{C}$ screening in general practice to underprivileged immigrants were gender (women were screened less for $\mathrm{HBV}$ and $\mathrm{HCV}$ infection) and being from a non-sub-Saharan African country (especially from North Africa) for all three viruses [43].

\section{Conclusions}

At a time when, in France, many people remain unaware of their HIV status, when the proportion of people screened late is not decreasing and when many practitioners are not adhering to the recommendations for universal screening in primary care [44], it seems more important than ever that HIV screening services target not only the high-risk populations, but also those with a lower self-perceived risk of infection and/or at high risk for stigma, such as younger and older people, those in a steady relationship, and men living in immigrant neighborhoods. In 2016, a new French policy will merge (previously split) HIV, viral hepatitis and/or STI screening centers into comprehensive sexual health centers, which will provide all these screening tests, as well as information, contraception, STI care and linkage to specialist care. This will possibly increase access to HIV screening for those who stay away from HIV testing services. Also, community-based and/or outreach, combined, rapid screening test services should not be limited in France to MSM communities but rather extended to other communities, in particular, immigrant communities other than just that from sub-Saharan Africa.

\section{Competing interests}

The authors have declared that no financial competing interests exist.

\section{Authors' contributions}

All the authors contributed to the study. VM, AL, PC and DC had the idea for the study. All the authors substantially contributed to the conception and design of the study. VM, PC, AL and RDS created the questionnaire used in the study. AL and MCG were responsible for the data management. VM and MCG performed the statistical analyses and presented the results. All the authors participated in the interpretation of the results. VM, PC and RDS drafted the article. All the authors critically reviewed the manuscript for important intellectual content and approved the final version."

\section{Funding}

The SIRS survey was supported by the Institute for Public Health Research (IReSP) (grant number 2008-87; URL:http://www.iresp.net), the French National Agency for Research on AIDS and Viral Hepatitis (ANRS) (grant number 2009-072), and Sidaction.

The funders had no role in the study design, data collection and analysis, decision to publish, or preparation of the manuscript.

\section{Author details}

'Sorbonne Universités, UPMC Univ Paris 06, INSERM, Institut Pierre Louis Institute d'Epidémiologie et de Santé Publique (IPLESP UMRS 1136), Department of Social Epidemiology, F-75012 Paris, France. ${ }^{2}$ Sorbonne Universités, UPMC Univ Paris 06, INSERM, Institut Pierre Louis Institute d'Epidémiologie et de Santé Publique (IPLESP UMRS 1136), Department of HIV Clinical Research, F-75013 Paris, France.

Received: 2 April 2015 Accepted: 1 July 2015

Published online: 22 July 2015

\section{References}

1. De Wit JB, Adam PC. To or not to test: psychosocial barriers to HIV testing in high-income countries. HIV Med. 2008;9 Suppl 2:20-2. doi:10.1111/ j.1468-1293.2008. 00586.x.

2. Deblonde J, de Koker P, Hamers FF, Fontaine J, Luchters S, Temmerman M. Barriers to HIV testing in Europe: a systematic review. Eur J Publ Health. 2010;20(4):422-32. doi:10.1093/eurpub/ckp231.

3. Stolte IG, Gras M, Van Benthem BH, Coutinho RA, van den Hoek JA. HIV testing behaviour among heterosexual migrants in Amsterdam. AIDS Care. 2003;15:563-74.

4. Fakoya I, Reynolds R, Caswell G, Shiripinda I. Barriers to HIV testing for migrant black Africans in Western Europe. HIV Med. 2008;9 Suppl 2:23-5. doi:10.1111/j.1468-1293.2008.00587.x.

5. Alvarez-del Arco D, Monge S, Azcoaga A, Rio I, Hernando V, Gonzalez C, et al. HIV testing and counselling for migrant populations living in high-income countries: a systematic review. Eur J Publ Health. 2011;23(6):1-7.

6. Dias S, Gama A, Severo M, Barros H. Factors associated with HIV testing among immigrants in Portugal. Int J Public Health. 2011;56:559-66.

7. Hoyos J, Fernandez-Balbuena S, de la Fuente L, Sordo L, Ruiz M, Barrio G, et al. Never tested for HIV in Latin-American migrants and Spaniards: prevalence and perceived barriers. J Int AIDS Society. 2013;16:18560. http://dx.doi.org/10.7448/IAS.16.1.18560.

8. Le Vu S, Lydié N. Practices of HIV testing among people from sub-Saharan Africa in the lle de France, 2005. Bull Epidémiol Hebd. 2008;7-8:52-5 (in French).

9. Lassetter $\mathrm{JH}$, Callister LC. The impact of migration on the health of voluntary migrants in western societies. J Transcul Nurs. 2009;20:93-104.

10. Lapostolle A, Massari V, Chauvin P. Time since the last HIV test and migration origin in the Paris metropolitan area. France Aids Care. 2011;23(9):1117-27.

11. Halfen S, Embersin-Kyprianou C, Grémy I, Fauvelot S. Suivi de l'infection à VIH/sida en Ile de France. Bul Santé ORS Ile-de-France. 2011;15:1-8.

12. Cazein F, Barin F, Le Strat Y, Pilonnel J, Le Vu S, Lot F, et al. Prevalence and characterisitics of individual with undiagnosed HIV infection in France: evidence from a survey of hepatitis B and C seroprevalence. J Acquir Immune Defic Syndr. 2012;60(4):e114-7.

13. Supervie V, Ndawing JDA, lodi S, Costagliola C. The undiagnosed HIV epidemic in France and its implications for HIV screening strategies. Aids. 2014;28(12):1797-804. doi:10.1097/QAD.0000000000000270. 
14. Lot F, Pillonel J, Pinget R, Cazein F, Bernillon P, Leclerc M, et al. Les pathologies inaugurales de sida, France, 2003-2010. Bulletin Epidémiologique Hebdomadaire. 2011;43-44:454-7 (in French).

15. Chauvin P, Parizot I. Les inégalités sociales et territoriales de santé dans I'agglomération parisienne. Une analyse de la cohorte Sirs. In: In: Les cahiers de I'ONZUS. Saint-Denis La Plaine: Délégation interministérielle à la ville; 2009. p. 105.

16. Vallée J, Chauvin P. Investigating the effects of medical density on healthseeking behaviours using a multiscale approach to residential and activity spaces. Results from a prospective cohort study in the Paris metropolitan area, France. Int J Health Geogr. 2012;11:54. doi:10.1186/1476-072X-11-54.

17. Massari V, Lapostolle A, Cadot E, Parizot I, Chauvin P. Gender, socio economic status, migration origin and neighbourhood of residence are barriers to HIV testing in the Paris metropolitan area: results from the SIRS cohort study of 2005. Aids Care. 2011;23(12):1609-18. doi:10.1080/ 09540121.2011.579940. Epub 2011 Jun 28.

18. Vallée J, Cadot E, Grillo F, Parizot I, Chauvin P. The combined effects of activity space and neighbourhood of residence on participation in preventive health-care activities: The case of cervical screening in the Paris metropolitan area (France). Health Place. 2010;16:838-52. Epub 2010 Apr 24.

19. Claudot F, Alla F, Fresson J, Calvez T, Coudane H, Bonaïti-Pellié C. Ethics and observational studies in medical research: various rules in a common framework. Int J Epidemiol. 2009;38:1104-8.

20. Massari V, Dorléans Y, Flahault A. Trends in HIV voluntary testing in general practices in France between 1987 and 2002. Eur J Epidemiol. 2005;20(6):543-7.

21. Institut national de la statistique et des études économiques. Definitions and methods- Consumptions units. http://www.insee.fr/en/methodes/ default.asp?page = definitions/ unite-consommation.htm.

22. Bajos N, Ducot B, Spencer B, Spira A. Sexual risk-taking, socio-sexual biographies and sexual interaction: Elements of the French national survey on sexual behaviour. Soc Sci Med. 1997:44(1):25-40.

23. Bajos N, Bozon M. Enquête sur la sexualité en France - Pratiques, genre et santé. Paris: Editions La Découverte; 2008.

24. Hosmer DW, Lemeshow S. Applied logistic regression. New York: Wiley; 2000.

25. Larsen K, Merlo J. Appropriate assessment of neighborhood effects on individual health: integrating random and fixed effects in multilevel logistic regression. Am J Epidemiol. 2005;161(1):81-8. doi:10.1093/aje/kwi017.

26. Beltzer N, Saboni L, Sauvage C, Lydié N, Semaille C, Warszawski J, et al. An 18-year follow-up of HIV knowledge, risk perception, and pratices in young adults. Aids. 2013;27:1011-9.

27. Laporte A, Douay C, Detrez MA, Le Strat Y, Chauvin P. Psychiatric disorders among homeless people in Paris, France: a representative, population-based survey in 2009. New York Academy of Medicine: 9th International Conference on Urban Health; 2010. Abstract book: OS16.1.

28. O'Connell T, Rasanathan $\mathrm{K}$, Chopra M. What does universal health coverage mean? Lancet. 2014:383:277-79.

29. Grillo P, Vallée J, Chauvin P. Inequalities in cervical cancer screening for women with or without a regular consulting in primary care for gynaecological health, in Paris. France Prev Med. 2012;54(3-4):259-65. doi:10.1016/j.ypmed.2012.01.013. Epub 2012 Jan 24

30. Rondet C, Lapostolle A, Soler M, Grillo F, Parizot I, Chauvin P. Are immigrants and nationals born to immigrants at higher risk for delayed or no lifetime breast and cervical cancer screening? The results from a population-based survey in Paris metropolitan area in 2010. Plos One. 2014;9(1):e87046. doi:10.1371/journal.pone.0087046. eCollection 2014.

31. Riley G, Baah-Odoom D. Do stigma, blame and stereotyping contribute to unsafe sexual behaviour? A test of claims about the spread of HIV/AIDS arising from social representation theory and the AIDS risk reduction model. Soc Sci Med. 2010;71(3):600-7.

32. Kesteman T, Lapostolle A, Massari V, Chauvin P. Impact of migration origin on individual protection strategies against sexual transmission of HIV in Paris metropolitan area, SIRS cohort study. Washington: AIDS Conference; 2012. Abstract No. A-452-0254-15154.

33. d'Ameida Wilson K, Dray-Spira R, Aubrière C, Hamelin C, Spire B, Lert F, et al. MSM over 50 years and not self-defined as gay more at risk of late presentation at HIV diagnosis: Results of the ANRS-Vespa2 study, France. Barcelona, Spain: XIth International AIDS Impact Conference; 2011. 29 September to 2 October 2013.
34. Lapostolle A, Massari V, Beltzer N, Halfen S, Chauvin P. Differences in recourse to HIV testing according to migration origin in the Paris metropolitan area in 2010. J Immigr Minor Health. 2013;15(4):842-5.

35. Delpierre C, Cuzin L, Lauwers-Cances V, Marchou B, Lang T. High-risk groups for late diagnosis of HIV infection: A need for rethinking test policy in the general population. AIDS Patient Care STDS. 2006;20:838-46. doi:10.1089/ apc. 2006.20.838.

36. Delpierre C, Cuzin L, Lert F. Routine testing to reduce late HIV diagnosis in France. Brit Med J. 2007;334(5):1354-6. doi:10.1136/bmj.39225.458218. 94.

37. Burns FM, Imrie J, Nazroo JY, Johnson AM, Fenton KA. Why the (y) wait? Key informant understandings of factors contributing to late presentation and poor utilization of HIV health and social care services by African migrants in Britain. AIDS Care. 2007:19:102-8.

38. Campbell T, Bernhardt S. Factors that contribute to women declining antenatal HIV testing. Health Care Women Int. 2003:24:544-51.

39. Burkholder GJ, Harlow LL, Washkwich JL. Social stigma, HIV/AIDS knowledge, and sexual risk. J Appl Bio-Behavior Res. 1999:4:27e44.

40. Goffman E. Stigma: Notes on the management of spoiled identuty. London: Penguin; 1990

41. Ministère de la Santé et des Sports. Plan national de lutte contre le VIH/ SIDA et les IST 2010-2014. Rapport du Ministère. Novembre 2010.

42. Champenois K, Cousien A, Cuzin L, Le Vu S, Deuffic-Burban S, Lanoy E, et al. Missed opportunities for HIV testing in newly-HIV-diagnosed patients, a cross sectional study. BMC Infect Dis. 2013;13:200. doi:10.1186/1471-2334-13-200.

43. Rigal L, Rouessé C, Collignon A, Domingo A, Deniaud F. Factors associated with the lack of proposition of HIV-AIDS and hepatitis B and C screening to underprivileged immigrants. Rev Epidemiol Sante Publique. 2011;59:213-21. doi:10.1016/j.respe.2011.01.007. Epub 2011 Jul 2. (in French).

44. Conseil National du Sida CNS): Avis suivi de recommandations sur le bilan à mi-parcours du plan national de lutte contre le VIH/sida et les IST 2010-2014. http://wwwcns.sante.fr/spip.php?article495.

\section{Submit your next manuscript to BioMed Central and take full advantage of:}

- Convenient online submission

- Thorough peer review

- No space constraints or color figure charges

- Immediate publication on acceptance

- Inclusion in PubMed, CAS, Scopus and Google Scholar

- Research which is freely available for redistribution

Submit your manuscript at www.biomedcentral.com/submit
C Biomed Central 